\title{
Psychological Problems and Challenge In EFL Speaking Classroom
}

\author{
Win Listyaningrum Arifin \\ Gadjah Mada University \\ win.listyaningrum.a@mail.ugm.ac.id \\ DOI: http://dx.doi.org/10.18326/rgt.v10i1.29-47
}

\section{ENGLISH ABSTRACT}

Psychological aspect regarding to learning attitudes plays in determining learning achievement. Psychological problems also involve not only to the students but also to teachers. Less-confidence, speech anxiety, and low self-esteem are almost common problem in classroom, and occur on both teachers and students. Students who have low of self-confidence are often hardly able to control themselves for public speaking in the classroom, e.g., governing his/ her behavior on that his/her peers think, losing belief on self, thinking that his/her friends dis-appraising, afraid of getting mistakes, etc. However, teachers who are low self-esteem and confidence also lose their performance and ability to manage their classroom optimally. Low self-esteem may caused by teachers' poor understanding on subject matter. Both of psychological problems impact on dis-effectiveness of classroom activities.

This paper takes accounts of some psychological problems of students and teachers in English speaking classroom and some guidelines to overcome. At the last discussion, this paper also provides some keys of how to make good classroom atmosphere.

Keywords: low self-esteem, low of self-confidence, anxiety, EFL speaking classroom

\section{INDONESIAN ABSTRACT}

Aspek psikologis mengenai sikap belajar berperan dalam menentukan prestasi belajar. Masalah psikologis juga mempengaruhi baik siswa maupun guru. Kurang percaya diri, kecemasan berbicara, dan rendahnya harga diri hampir umum terjadi di kelas, dan terjadi pada guru dan siswa. Siswa yang memiliki kepercayaan diri rendah seringkali tidak bisa mengendalikan diri untuk berbicara di depan umum di kelas, misalnya, mengatur tingkah lakunya seperti yang teman-teman harapkan, kehilangan kepercayaan pada diri sendiri, berpikir bahwa teman-temannya tidak memperhatikan, takut melakukan kesalahan, dan lain sebagainya. Namun, guru yang memiliki kepercayaan diri dan harga diri yang kurang juga kehilangan performa dan kemampuan mereka dalam mengelola kelas secara optimal. Harga diri yang rendah mungkin disebabkan oleh pemahaman guru yang kurang tentang materi pelajaran. Kedua masalah psikologis tersebut berdampak pada keefektifan kegiatan kelas.

Makalah ini membahas beberapa masalah psikologis siswa dan guru di kelas bahasa Inggris dan beberapa panduan untuk diatasi. Pada diskusi terakhir, makalah ini juga memberikan beberapa kunci bagaimana membuat suasana kelas yang baik.

Kata kunci: rendahnya harga diri, rendahnya kepercayaan diri, kecemasan, kelas berbicara 


\section{INTRODUCTION}

\section{Background of the Study}

It is should be taken into account that to gain successful education needs self-efficacy or self-esteem. Problems relate to the lack of self-efficacy doesn't only occur on students as participant of the learning process but in some cases also occur on teacher as practitioner of teaching. At once, we might ever find a teacher which looked like low self-esteem and show in-confidence performance; these phenomena will impact on the student learning perception, motivation and outcomes.

Nowadays, speaking is generally perceived as the most fundamental skill to acquire. Speaking in English for EFL students is not an easy task and needs much effort to produce acceptable words and utterances in English. The achievement measurement for English mastery is obviously seen through speaking competence. Teaching speaking in English as foreign language is perhaps the most emergent aspect of language skill, because it isn't only to build students' ability in producing verbal sentences, ability in producing good pronunciation, accuracy in the contact of speech and fluency but it also involves students' mental control as fortress of performance. As the most important aspect of language skill in term of communication, speaking is precisely often the one that student cannot gain enough competence during the English classroom. In many cases teachers are aware that speaking is the most difficult one and often become the most significant failure in English classroom.

The failures in English speaking classroom are not caused only by one or two aspects. Teachers' advance in speaking competence is not a guarantee that he/she can develop their students' speaking ability. Some teachers only sometime evaluate the problems in students speaking development from the students' behavior, and the lack of supporting media. It is very rare for teachers to find out the problems relate to the speaking failure in deeper aspect which involve students' psychology, however, psychological problems often influence on the ability, willingness and motivation of the students to achieve speaking competence. Lackconfidence, shyness, and fear are often psychological problem that we often meet in speaking classroom and learners' anxiety to speak English in the classroom is the result.

The psychological factors which influence on the failure of teaching process doesn't only occur to the students' classroom behavior, these also may occur on some teachers. When teachers are not able enough to control the classroom, it might be influenced by their mental 
and psychology. Lack of confidence, less of esteem, are the common psychological problem of teacher. Some factors may influence on such these phenomena, less of readiness, less of self-experiences, and poor of material understanding are examples that we often found in some teachers.

This paper is to arise psychological problems relate to speaking classroom, the writer tries not to address only to the students problems but also to teachers. For both teachers and students often faced similar problems such nervous, self-confidence, self-esteem which are common become speech anxiety that influence on their speaking performance in the classroom. Thus, this paper had explored to answer problems in speaking class concerning its psychological factors and challenges that had influenced for both teachers and students.

Juhana in 2012 had conducted research on psychological factors faced by senior high school students in Tangerang, Banten. His research revealed that psychological factors such as fear of making mistake, shyness, anxiety, lack of confidence and lack of motivation hinder students from speaking in English class. Those factors, like fear of making mistakes, were commonly caused by their fear of being laughed at by their friends. The possible solution to overcome those psychological factors, most students believed that motivating them to be more confident to speak English is worth considering. This finding suggests that the teachers should be more aware of their students' hindrance to speak in English class. He adds that motivating students to speak in English, to some extent, encourages them to actively participate in speaking in the class. All these suggest the importance of creating a supporting atmosphere of learning in the classroom (Juhana, 2012).

Another research is done by Ariyanti in 2016 to EFL students entitled "Psychological Factors Affecting EFL Students' Speaking Performance”. By conducting direct observation and interviews to Indonesian students at speaking class, the research showed that the students tend to feel anxious when performing their speaking because they are afraid of making mistakes. The feeling of fear of making mistakes, somehow related to the students' lack of self-esteem in using English so that they often combine their speaking with their mother tongue. Psychological barriers also appear in discussion session, where in this case some students do not want to participate because they are too, afraid of making mistakes, lack of self-esteem and motivation so they prefer to keep silent in the class. From the natural phenomenon happened in the speaking class, it can be concluded that psychological factors which hinder the students in performing their speaking are possibly caused by the feeling of 
too worried of making mistakes and the lack of self-esteem which are related to shyness and their anxiety level. By looking at this phenomenon, it is better for teacher to give their students assistance so that they can perform their English speaking better (Ariyanti, 2016).

Research done by Alessia Occhipinti (2009) on her thesis entitled "Foreign Language Anxiety in Class Speaking Activities" in a foreign language class in universities. The findings of the research are likely to support other studies, by asserting that foreign language anxiety is a common debilitating feeling which affects students in a variety of ways. This is also frequently happening to foreign language learners in many grades from high schools to universities. Particularly frequent during speaking activities, she thought that the awareness of such a feeling should be heightened and not be undervalued by teachers and learners. This could be realized through workshops or the adoption of certain teaching methodologies aimed to create a relaxed atmosphere in the classroom especially during speaking practices (e.g. Communicative Language Teaching; Natural Approach). Making students comfortable by avoiding activities which increase competitiveness or which threaten students' self esteem is very important. Working in small groups and discussing interesting topics are good activities that allow students to know each other and to practice the foreign language. Teachers could use gentle and flexible approaches of error correction, being friendly and with a good sense of humour. Thus, this research proposes strategies that can be applied to such similar environment in many parts of the world where speaking English is the subject of discussion.

Furthermore, this paper did not aim to make a generalization to similar speaking class. However, general phenomena sometimes occur in many situations of other speaking classes.

\section{RESEARCH METHOD}

This paper is a qualitative research by implementing a library research which was based on the personal observation to a speaking class. Here, the researcher analyzed detail information from participants to capture the whole pictures of phenomenon happened in natural condition (Creswell: 1998). This paper also documented writing or articles that also revealed similar themes on speaking class relating to the psychological condition, the challenging problems on this class, and also the coping strategies toward rising problems.

The subject is students from the fourth semester of English Department at State Islamic Institute Salatiga (Institut Agama Islam Negeri) Indonesia in 2016. Digging information from direct observation can meet the objectivity for the research and by applying such purposive 
sampling, the researcher had been assisted to obtain detail information related to the needs of the researcher (Gay, Mills \& Airasian, 2006).

In qualitative study, there are several techniques which can be used by the researcher to collect the data, they are observation, field notes, interview, questionnaire, and examining records (Gay, Mills \& Airasian, 2006). Meanwhile, here the researcher stated the study by doing direct observation to the participants directly while they were joining the class and performing their speaking competence after the lecturer's instruction. They performance was based on themes instructed earlier by the lecturer. While they were delivering the speech, the researcher made field notes to support the observation in picturing the phenomenon in the speaking class.

The behaviors conducted by the EFL students while they were speaking were recorded and noted. In addition, the attitudes of both lecturer and the students were also noted to figure out some psychological factors and challenge while the speaking class was happening. Interviews to some students, as well as to the lecturer, were also done to get a clear picture for the matter.

\section{Theoretical Framework}

\section{Psychological Problems Relate to the Students in Speaking Classroom}

For many students, apprehension levels are highest in the first lesson, when they meet the teacher, encounter the unknown, and, in some cases, make nerve-wracking presumptions about being expected to perform instantly, remember everything, and demonstrate their lack of skill to a roomful of people. It is vital for the ultimate success of the class that such tension can be defused early, and that students can be encouraged to overcome their inhibitions. The very first class is the perfect time for the language teacher to present a fun lesson that makes few demands and prepares students to open up in front of others.

Most beginner students are a little uncomfortable about to speak aloud or to be singled out to answer a question in any classroom. Some students are so embarrassed and self-conscious that they avoid the classroom conversation practice and participation that is essential for the development of language skills.

a. Low-Confidence

MacIntyre, Dornyei, Clement, and Noels (as cited in Hysook and Adam R. Lee 2004) suggested that self-confidence significantly contributes to the leaner's willingness to 
communicate in a foreign language. According to them, affective factors such as motivation, personality, and intergroup climate play important role in determining. James Manktelow \& Amy Carlson categorize the differences between self-confident and low self-confident such as in the following table:

\begin{tabular}{|ll|}
\hline \multicolumn{1}{|c|}{ Self-Confident } & \multicolumn{1}{c|}{ Low Self-Confidence } \\
\hline $\begin{array}{l}\text { Doing what you believe to be right, } \\
\text { even if others mock or criticize you } \\
\text { forit. }\end{array}$ & $\begin{array}{l}\text { Governing your behavior basedon } \\
\text { what other people think. }\end{array}$ \\
\hline $\begin{array}{l}\text { Being willing to take risks and go the } \\
\text { extra mile to a chieve better things. }\end{array}$ & $\begin{array}{l}\text { Staying in your comfort zone, fearing } \\
\text { failure and so avoid taking risks. }\end{array}$ \\
\hline $\begin{array}{l}\text { Admittingyour mistakes, and } \\
\text { leaming from them. }\end{array}$ & $\begin{array}{l}\text { Working hard to cover up mistakes and } \\
\text { hoping that you can fix the problem } \\
\text { before anyone notices. }\end{array}$ \\
\hline $\begin{array}{l}\text { Waiting for others to congratulate } \\
\text { you onyour accomplishments. }\end{array}$ & $\begin{array}{l}\text { Extollingyour own virtues as often as } \\
\text { possible to as many people as possible. }\end{array}$ \\
\hline $\begin{array}{l}\text { Accepting compliments graciously. } \\
\text { prospectus. I'm pleased you } \\
\text { recognize my efforts." }\end{array}$ & $\begin{array}{l}\text { Dismissing compliments offhandedly. } \\
\text { "Oh that prospectus was nothing really, }\end{array}$ \\
\hline
\end{tabular}

A teacher may be experienced to find his/her student less of willingness and isolates among their friends. This symptom generally influenced by the lack of confidence in the individual of the students. Students who are low in confidence also have low self-efficacy that is being influenced by the feeling that they are 'stupid', 'worthless', not as 'bright' as others, they do not know that everyone else is not probably better than they are.

In the previous table, the psychological aspects of low self-confident may occur in speaking classroom where teacher meet the students indicate to:

1. Govern his/ her behavior on that his/her peers think, lose belief on self, and think that his/her friends dis-appraising him/her presentation.

2. Afraid of getting mistakes and forcing his/her self covering mistakes during presentation

3. Too much extolling others

4. Dismiss compliments offhandedly. "Oh that was nothing really, anyone could have done it." 
Hysook and Adam R. Lee (2004) in their conclusion of their research suggested that teachers should pay more affective domains. Technically, teacher arise students' sense of belief on self. Elaine Sihera (2009) stated that effective strategies to overcome student confidence should include such following elements:

1. Gaining the student's trust

As the teacher, the best way to gain trust is to be consistent and firm with clear boundaries, to be accessible where possible, to find opportunities to engage the student to make them feel involved and valued and to be positive more than negative.

2. Setting personal routine that students can control

Routines provide familiarity, regularity, boundaries and frameworks which gradually boost feelings of being able to cope through repetition and presentation practice. The more something is established, repeated and becomes familiar the more it loses its mystery, the more it is learned and the more it can be controlled. For example, setting times to do their homework, ways to organize their work and not using work times for leisure are easy routines they can follow. By setting clear routines for students, they are given a sense of security, a sense of purpose and security and a base from which to gradually build their confidence.

3. Encourage positive reinforcement

The hallmark of positive reinforcement is affirmation and encouragement of the individual: praise and more praise for any effort. This is very important for increasing student confidence. Positive reinforcement in the classroom does not mean no criticism at all, that would be unrealistic. What it means is that the quality and form of feedback to students are very important. There should always be praise before blame, with regards to all efforts.

4. Discourage a perception of being only 'right' or 'wrong'

Very few things are totally 'right' or 'wrong' on a cultural or social level. Not even deviance. It is all a question of what is 'appropriate' for a given time. Hence talking in the playground might be acceptable but chatting in a classroom at a particular teaching moment becomes 'inappropriate' for obvious reasons, though it might even be allowed at another teaching time. Explaining what is inappropriate to students and why it could be so takes away the need for the teacher to be 'right' or the students to be 'wrong' and educates them in how they can regulate their own behavior confidently around what is 
mutually acceptable. This approach is crucial to encourage them to experiment and use their initiative. If they won't be 'wrong' then they are free to find more appropriate responses.

5. Encourage students to be themselves

In such cases, encourage them to talk about their lives, their cultures and their fears. Then interweave their contributions in the daily life of the classroom. This is very important because minority students are exposed from the very first day to majority culture and are expected to assimilate it. By being encouraged to be themselves they too can feel valued at the same time while undergoing integration.

6. Encourage personal perspectives

By encouraging students to share how they see the world, their perceptions can be used to frame the actual reality of classroom activity so that they do not feel excluded at any time.

b. Anxiety (Shyness and fear)

Speech anxiety is a general term for the sense of fear that overtakes a student when he/she is called upon to speak or otherwise perform in front of the class. There are other terms to refer to it: anxiousness, nervousness, stage fright, etc. Anxiety usually strikes when someone has to deliver a presentation before a group of people and it is another special case of what is commonly known as shyness.

\section{Shyness}

Shyness is a psychological state that causes a person to feel discomfort in social situations in ways that interfere with enjoyment or that cause avoidance of social contacts altogether. Shyness can vary from mild feelings to moderately uncomfortable in social circumstances to debilitating levels of anxiety that interfere in people with the process of socialization (social withdrawal).

Most classrooms have one or more students who struggle with making themselves heard or participating in class discussions. These students are usually called "shy" because they may speak softly, prefer to work independently or refuse to speak up at all. Often these students are good with written assignments or tests, but fail in areas that require participation with classmates or presentations in front of other students.

Shy students are often too afraid to speak up in a public and classroom setting. So many causes may impact on this case, a student which is previously high-confidence 
can be suddenly become talk less due to he/she made a mistake, it is often influences by less of mental power that prop his/her confidence. Shy student can also be the result of not interacting too often with peers. This student fear too much of being asked and to answer questions inside the classroom, even more to speak in front of the class.

The major behavioral components of excessive shyness in student are as follows:

- Difficulty talking, stammering, stuttering, blushing, shaking, sweating hands when around others

- Difficulty thinking of things to say to people

- Absence of outgoing mannerisms such as good eye contact or an easy smile

2. Fear

A great fear that many people have is speaking in front of a group or audience. The primary reason is that they are afraid of looking foolish in front of other people. Speaking in front of others, consistently counts as one of the foremost fears of individuals. Indeed, many students place speaking presentation ahead of death itself in their relative ranking of fears. It is no wonder, then, that many students tend to avoid situations where they are expected to speak or perform in front of the class, for example, a student may struggle through, or seek to avoid altogether, only to practice a little presentation in front of his/her friends. A teacher can recognize that his/her student is suspected by Speech anxiety in both physical and psychological symptoms.

In general, student which is suspected by Speech anxiety in both physical and psychological will show the following symptoms:

- Trembling or shaking body and sweat profusely

- Their hands especially begin to feel moist

- Their heart rate begins to quicken

- Their mouths become parched

- Their mind begins to race

- Their thoughts become jumbled

\section{b.1. Strategies to overcome the student's anxiety}

There are useful strategies to help these young, shy or withdrawn students to be out of their shells through active teacher partnership, peer involvement.

Here are some strategies: 
- Re-arrange seating often so they make new friends and re-shuffle again until the student befriends all of his classmates.

- Encourage responses from them specifically during class presentation.

- Give special tasks to especially shy students to make them feel important and make them responsible students.

- Engage in private conversations if necessary to monitor their progress and report them to the students' parents.

- Exhibit the good artwork or assignment of your shy students to develop their selfworth and confidence.

- Give them specific roles in the classroom that will initiate interactions too among them as students.

- Peer Involvement, teacher can ask some peers or students to become confederates and help shy children cope.

- Teachers, too, can create activities that require the formation of small group and cooperative learning activities.

Considering that shyness can sometimes be the symptom of a psychological issue or a troublesome home life, parental involvement can be the key.

\section{Low Self-Esteem Relate to the Teachers' Problems}

Fernando Rubio (2007) stated that basically, self-esteem is a psychological and social phenomenon in which an individual evaluates his/her competence and own self according to some values, which may result in different emotional states, and which becomes developmentally stable but is still open to variation depending on personal circumstances and may also occur in classroom.

Pine and Boy (1997) express "pupils feel the personal emotional structure of the teacher long before they feel the impact of the intellectual content offered by that teacher", in the other hand, Krashen and Garcia (1981) state that the teacher's attitudes have a direct effect on the students' motivation, self-esteem, and anxiety level. Teacher which has strong belief oh his/her individual competence will have good self-esteem and confidence for his/her attitude in the classroom, on the other way, teacher which has less belief on his/her individual competence will be low self-esteem and it also will influence on his/her classroom activity. Some factors which may cause on the lack of teacher confidence can be: 
1. Poor understanding on subject matter

It often occur in almost many teachers which do not prepare enough the subject matter, or even ignore such simple thing that considered as not important thing.

2. Less of self experiences and cultural insights

Teacher which less self-experience and language cultural insight will looked like stupid person when he/she cannot explain how the language in accordance with the culture.

3. Forget his/her position

In the instructional process, a teacher has to be in harmony with the students, but it will be dangerous if the teacher is too close to his/her students and lost his/her position as instructor or classroom leader.

\section{The Effect of the Low Self-Esteem Teacher}

According to Honeyford (1982) a major limiting factor in any classroom is the teacher not only do his character, play his personality and competence in a large part in determining the atmosphere of the lesson, but the teacher also performs a key role in influencing the pupils' view of himself and the sort of progress he/she makes. Psychologically, teacher which has less self-esteem will lead his/herself into:

passive teacher, he/she simply relies on the same old teaching techniques day after day, further the lack of esteem teacher also will not respect on the classroom management which is the linchpin that makes teaching and learning achievable, teacher with lass of esteem will not be able to manage the students and lead them into positive learning situation due to the less student respect on him/her.

a. How to develop teacher self-esteem

Confidence is a key to being a successful teacher. A confident teacher generates respect among his students and inspires them to listen and learn from him. Lack of confidence in a teacher is damaging not only to the career, but also to the students' ability and willingness to learn. Every teacher should take the time to develop confidence. Becky Hawk suggests for some aspects which are considered as important thing to develop teacher confidence are as follow:

1. Know the subject matter.

It is important that a teacher must keep up in his/her field and stay a few steps ahead of the students. If a teacher is unsure of the subject matter or unprepared for the lessons, 
he/she will neither feel nor seem confident. Thus, this is very important to carefully prepare and review each lesson in order to boost his/her own confidence and teach authoritatively.

2. Step outside the box with the teaching on occasion.

It is a must to demonstrate the teacher's knowledge to students in class. He/She should go beyond simple explanations occasionally to show the competence. Don't overwhelm the students, but do show them that the teacher knows more about what he/she is teaching than they do. This is also important to use creativity and don't be confined to a mundane, ordinary teaching style.

3. Remember a teacher's position.

As a teacher has been hired to teach because the employer thought he/she is competent for the task. The position should give the confidence for teacher. It is important not to let students manipulate or make the teacher feels inadequate. They must respect the teacher not only for his/her knowledge, but also for his/her position's sake.

4. Observe the students.

Work to meet their needs and keep them engaged and excited about the subject matter.

5. Teacher's appearance can have an effect on the way you feel as a teacher.

This is absolutely suggested to keep up teacher's physical appearance. If a teacher does not feel good about himself, this could have an effect on confidence as a teacher. The way to dress in a way that makes a teacher feels confident is necessary.

\section{Keys to Encourage Reluctant Learners in the Speaking Classroom}

Nation (2007) suggests of these techniques based on the Cognitive, Affective and Situational Framework put forth by:

1. Reduce the Level of Task Difficulty

From Nation's point of view, if students do not know enough, they will not be able to perform the task well, and this is one of the causes of students' unwillingness to speak. The following techniques are practical in dealing with the problem:

a. Give Students More Time to do Tasks

This can be done by giving students more preparation time. Alternatively, allow them to perform oral tasks without time pressure (Ellis, 2005) by giving them enough time to plan for and perform a task at the same time.

b. Bring the Tasks within Students' Experience 
According to Nation (2000), teachers can create recalling and sharing-experience opportunities for students to make use of their background knowledge and experience in doing the tasks. Key oral skills and strategies should be pre-taught in preparing students for communicative tasks. Also, it is advisable that teachers grade the difficulty level of oral tasks to suit their students' communicative ability.

c. Allow Students to Collaboratively Solve Communicative Tasks (Nation, 2000) When organizing pair work and group work, make sure that every student's participation is necessary for the task to be completed. It is best if each participant has "unique, essential information" or distinctive role to play (Nation, 2007).

d. Provide Students with Task Guidance

Nation (2000) suggests providing this kind of support through repeated input, guiding questions, multiple choices, and so on.

e. Attend to Individual Students' Needs and Ability

In a class of heterogeneous communicative ability, the teacher should not expect every student to perform at the same level. Likewise, different kinds of tasks can be devised to suite different levels. Alternatively, task demands can be adjusted according to individual levels of oral competence.

2. Promote Positive Attitudes among Students

Students who hold positive attitudes towards language learning are less likely to suffer from language learning anxiety and more likely to participate actively in learning tasks (Tsiplakides \& Keramida, 2010). The techniques suggested below can help the teacher build up positive attitudes among students so that they can feel free to speak in the language class.

a. Change Students' Negative Beliefs and Attitudes towards Mistakes

Teachers can discuss with students the value of language use even if it is not fluent and accurate (Young, 1991; Nation, 1997). Meaning-focused oral activities (Nation, 2007) can also be used frequently with the goal clearly stated. When students are rewarded for successfully conveying a message, they will gradually change their perceptions about mistakes and language use. The teachers' tolerance of mistakes also needs to be made clear because there is no point in trying to change students' attitudes when the teacher still keeps them. 


\section{b. Boost Students' Self-confidence}

This can be done by creating various opportunities for classroom success in using spoken English (Oxford, 1999). A sense of success and high self-perceived communication competence can be easily achieved by students if easy tasks with clear and simple goals are used in the first place. The level of difficulty can be increased over time as students' ability develops. General goals should be broken down into smaller, short-term goals so that even when students do not achieve the final goals they still feel a sense of achievement for completing some of the subgoals. Also, students should be rewarded once they achieve one or more goals.

c. Lower Students' Anxiety in the Classroom

According to Young (1991), teachers can start with finding out what students are anxious about. Then teachers can help them ease some of their irrational fears and teach them strategies such as self-talks and doing relaxation exercises to deal with fears.

\section{Build a Supportive Learning Environment}

Once students feel a sense of support from their teacher and peers, it is likely that they will be more willing to speak in the target language. The following are some techniques that teachers can use to create a supportive atmosphere for students.

a. Encourage Peer Support in the Classroom

Tsui (1996:160) suggests that "allowing students to check their answers with their peers before offering them to the whole class also encourages students to speak up." Similarly, they can be allowed to have a discussion with their peers before talking to the whole class so that they will feel more confident in speaking English.

b. Be Sensitive When Assigning Students into Groups Many students tend to talk more with their close friends. Therefore, when organizing group work, the teachers should take account of and accommodate these personal traits. For example, students can be allowed to choose who they are going to work with.

c. Tolerate L1 Use When Appropriate

According to Nation (1997), using L1 can help learning in many cases. The teachers' attitude to L1 use should be positive so that students are not humiliated 
when they use L1 to assist L2 development. When L1 use is not necessary, the teachers should tactically lead students back to using English.

d. Make the Classroom Environment a Non-threatening Place (Oxford, 1999)

The classroom should be an environment where students are not scared of making communicative mistakes and being ambiguous in communicating. Situations that make students anxious such as correcting mistakes on the spot, calling on students at random (Young, 1991), calling on students without allowing them to prepare for the answers, and calling on a student simply because he/she is quiet or not concentrating should be avoided. Otherwise, what the teacher gets from students is usually not desired language use but threatened faces and this will have negative effects on the students' feelings and attitudes afterwards.

e. Introduce Opportunities for Students to Speak English outside the Class Opportunities such as English clubs inside and outside the school should be introduced to students. The benefits of and tactics for participation should be clearly explained to them. Classroom activities can also be linked to these club activities. For example, students can be asked in the class to report on their participation in the clubs or they can share their experience with their classmates. More opportunities for speaking English outside the class can also be created. For instance, students can be put into groups to do some projects and if possible, their group work should be recorded. They may also be asked to carry out and record interviews with foreigners who are visiting or living around.

The solutions in this category are ranked from the most specific, day-to-day basis to the most long-term one. Although short-term and long-term measures should be taken in parallel, it is believed that short-term solutions should receive priority to be completed first. This will create more opportunities for the long-term ones to be successful.

\section{DISCUSSION}

Based on the data gained from direct observation in speaking class of forth semester students of IAIN Salatiga, the researcher found that the students had shown similar performances. Psychological factors concerning on low self confidence, low self esteem, anxiety, less concentration and the like were common features while the students were 
performing the speech. Though they had prepared the material the days before and had been determined by themes, including the time duration, they performance was obviously influenced by their psychological conditions. To note, not all students were bad in the performance, there were some who were good at speaking. However, still, the psychological conditions had determined the flow of the presentations. These conditions had driven them to keep repeating the words or sentences, sometimes unintentionally inserted fillers e.g. hmm, err, etc., scratched hair, looked at the ceiling, moved/shakes the body gently, or used Bahasa Indonesia to intensify the lost words they had prepared. A kind of clinical interviews was then conducted to some students, surprisingly that they were afraid and ashamed of making mistakes to the lecturer. They were also anxious to what other friends perceived on them. The English using which was not to their customs was then used to make a kind of permission so that their speaking ability was not good. They excused that English through speaking was a hard skill to achieve.

The lecturer's readiness in delivering a speaking class was also important. After the speaking class, the lecturer was then interviewed to investigate the matter. The lecturer revealed the fact that for some students the themes of the subject were quite difficult. When the lecturer asked the students to explore and to elaborate the themes from daily situations, the students felt unpleased and looked worried. The lecturer stated that she was quite supportive to the students and even gave situational examples. In fact, this was a difficult task as she must prepare the information concerning the students' records. She had to ask other colleagues about the students' situations but these were not too useful as the students' situation in perceiving each subject would be varied. Later, she tried to create a comfort condition by inserting humor while she was teaching or commenting the students' performance. She encouraged the students that this speaking class was ahead process to master English.

However, based the interview with the lecturer, she stated that she had made an abridgement by giving mutual supports to the students. Here, she did not make her position as the lecturer as the solely orientation as she thought that this was not again the day where a teacher perceived himself as the center of the universe/class.

Form the data, the researcher then concluded that the speaking class had been done effectively as the lecturer really understood the process of the students' competence flows. This was a mutual relationship which was very important to engage education especially in 
EFL situation. The speaking aim is not merely about mastering the language but also about understanding the culture of communicative direction. Of course, any psychological situation and challenge for such condition should be taken into account by implementing good strategies in dealing with problems in speaking class.

\section{CONCLUSION}

Psychological aspect in English classroom needs to be considered because it will impact on students affective perceptions, teachers are not demanded to enrich in their pedagogical competence, but further they have to develop psychological awareness. Succeed or failure of an instructional process depends on how teacher manage and perform. The aspects which are part of learning succeed might be psychological and individual. A language teacher is demanded not only to be able in transforming knowledge of language but also have to be able to involve culture of language in language classroom, teacher attitude is also an important aspect gaining the success of learning. Teachers need to adapt these techniques to suite their class situation. Furthermore, many of these solutions should be implemented simultaneously so that they can supplement each other in tackling the problem from different angles, creating a better chance that the problem will successfully be solved.

\section{REFERENCES}

Ariyanti (2016). Psychological factors affecting EFL students' speaking performance. ASIAN TEFL Vol. 1 No.1, 2016 www.asian-tefl.com e-ISSN: 2503-2569, p-ISSN: 2527-5038 doi: http://dx.doi.org/10.21462/asiantefl.v1i1.14

Brown, D. (2001). Principles of language learning and teaching. New York: Longman.

Creswell, John W. (1998). Qualitative inquiry and research design: Choosing among five traditions. Thousand Oaks, California: SAGE Publication Inc.

Dornyei, Z. (1998). Motivation in Second and Foreign Language Learning. In Cai Xi. (2008). Affective Value of Cooperative Learning in Foreign Language Learning and Teaching. Shanghai International Studies University. 
Duncan Sidwell, (2006). Encouraging talk in the classroom, Retrieved from http://www1.open.edu.cn/elt/3/ htm, [01,11, 2011]

Ellis, R. (2005). Planning and task-based performance: Theory and research. In R. Ellis (Ed.), Planning and Task Performance in a Second Language (pp. 3-34). Amsterdam: John Benjamins Publishing Company.

Gay, L. R. Mills, Geoffrey E, \& Airasian, Peter. (2006). Educational research: Competencies for analysis and applications. Columbus: Pearson Merrill Prentice Hall.

Honey Ford, R. (1982). Starting Teaching, London, UK: Croon Helm Ltd.

Hysook and Adam R. Lee ( 2004). Leaners' anxiety, self-conficence and oral Performance Kunsan National University, Concordia Universty

James Manktelow \& Amy Carlson. -. Building Self-Confidence, retrieved from http://www.BrickstoneSquare [22. Sep. 2011]

Juhana (2012). Psychological Factors That Hinder Students from Speaking in English Class (A Case Study in a Senior High School in South Tangerang, Banten, Indonesia). Journal of Education and Practice. ISSN 2222-1735 (Paper) ISSN 2222-288X (Online) Vol 3, No 12, 2012

McIntyre, P.D., Dornyei, Z., Clement, R., \& Noels, K. (1998). Conceptualizing willingness to communicate in a L2; situation model of L2 confidence and affiliation. Modern language journal 82, 545-62

McCroskey, J.C. and Richmond, V.P. (1991). Quiet Children and the Classroom Teacher. ERIC Clearinghouse on Reading and Communication Skills.

Nation, P. (1997). L1 and L2 use in the classroom: a systematic approach. TESL Reporter, 30(2). 19-27.

Nation, I.S.P. (2000). Creating, adapting and using language teaching techniques. English Language Institute Occasional Publication No. 20. Victoria University of Wellington. 
Nation, I.S.P. (2007). Vocabulary learning through experience tasks. Victoria University of Wellington: LALS.

Nation, P. (2007). Frameworks for problem solving. Lecture Notes for LALS 516: Classroom Management. Wellington: Victoria University of Wellington.

Occhipinti, Alessia (2009). Foreign Language Anxiety in Class Speaking Activities. A Thesis Presented to The Department of Literature, Area Studies and European Languages The University of Oslo

Oxford, R.L. (1999). Anxiety and the language learner: new insights. In J. Arnold (Ed.), Affect in Language Learning (pp. 58-67). Cambridge: Cambridge University Press.

Tsiplakides, I. and Keramida, A. (2010). Promoting positive attitudes in ESL/EFL classes. The Internet TESL Journal, XVI(1). http://iteslj.org/Techniques/TsiplakidesPositiveAttitudes.html

Tsui, A.B.M. (1996). Reticence and anxiety in second language learning. In K.M. Bailey and D. Nunan (Eds.), Voices from the Language Classroom: Qualitative Research in Second Language Education (pp. 145-167). New York: Cambridge University Press.

Yan Chuanhai \& Zhang Meijuan. (2002). Affective Factors in Foreign Language Teaching. Foreign Language World.

Young, D.J. (1991). Creating a low-anxiety classroom environment: What does language anxiety research suggest? The Modern Language Journal, 75 (iv), 42 